\title{
ENERGY PROPERTIES OF MULTIFLORA ROSE AND ENVIRONMENTAL BENEFITS FROM THE COMBUSTION OF ITS BIOMASS
}

\author{
Alina Kowalczyk-Juśko ${ }^{1}$ \\ 1 Faculty of Production Engineering, University of Life Sciences in Lublin, Leszczyńskiego 7 St., 20-069 Lublin, \\ Poland, e-mail: alina.jusko@up.lublin.pl
}

Received: 2016.08.01

Accepted: 2016.09 .26

Published: 2016.11.01

\begin{abstract}
The article presents the results of a study on multiflora rose, one of the energy crop plants. The yield of aerial parts was determined in a field experiment, and the calorific value and chemical composition of the biomass were determined in laboratory tests. The results were used to calculate the amount of hard coal that can be replaced by multiflora rose biomass and the air pollution emissions from combustion of coal and multiflora rose. Combustion of multiflora rose biomass from an area of 1 ha in place of hard coal with equivalent energy value was found able to reduce emissions of $\mathrm{SO}_{2}$ by $98.9 \%, \mathrm{NO}_{2}$ by $27.8 \%$, particulates by over $18 \%$ and $\mathrm{CO}$ by $8.5 \%$. The actual $\mathrm{CO}_{2}$ emissions from biomass combustion proved somewhat higher than in the case of coal; however, carbon dioxide emitted into the atmosphere during combustion of plant biomass is equal to the amount taken in by the plants during their growing period. Therefore the $\mathrm{CO}_{2}$ emissions are considered to be zero.
\end{abstract}

Keywords: biomass, multiflora rose, energy properties, environmental benefits

\section{INTRODUCTION}

By replacing fossil fuels (hard coal and petroleum) with solid and liquid biofuels, it is possible to reduce environmental pollution while conserving mineral resources for future generations. These measures are consistent with the principle of sustainable development [Kowalczyk-Juśko et al. 2007]. An important characteristic of biomass as fuel is its lower air pollution emissions. The most important ecological effect of biomass combustion is sustainable $\mathrm{CO}_{2}$ emissions, mainly owing to the fact that the carbon dioxide released into the environment was previously taken in from this environment by the plants. Therefore the $\mathrm{CO}_{2}$ emission factor used in monitoring systems is zero [Regulation... 2008].

There is a wide assortment of crop plants that can be used for energy purposes. These are perennial and annual species specially cultivated as a source of biomass. Plant by-products and waste can also be exploited for energy purposes [Burczyk 2011, Kołodziej, Matyka 2012]. One of the species proposed for cultivation for energy purposes is multiflora rose (Rosa multiflora Thunb.). This is a perennial shrub with low water and soil requirements and substantial yield potential [Chołuj et al. 2010, Kieć et al. 2011, Tworkowski et al. 2010]. Previous research on this species indicates that its chemical composition and energy parameters are comparable to those of other types of woody and semi-lignified biomass [Tworkowski et al. 2010, Kościk 2007].

Assessment of the environmental impact of biomass combustion is complex. The most reliable method is to evaluate emissions using various fuels in specific energy boilers. If there are no actual data on emissions, they must be estimated using appropriate factors. This was the method used in the present study.

\section{MATERIALS AND METHODS}

A field experiment was conducted at the Experimental Station in Zamość, University of Life Sciences in Lublin. The subject of the experiment 
was the Jatar cultivar of the perennial shrub multiflora rose (Rosa multiflora Thunb.). The area of the experimental plot was 0.05 ha. Seedlings were planted at $0.75 \times 0.50 \mathrm{~m}$ spacing. The plants were mowed beginning in the second year of vegetation. The analysis was conducted on one-year shoots on five-year rootstock. Biomass was collected in winter (February), as this is the time of year when biomass is typically acquired for energy purposes.

Analysis of energy parameters was carried out in the chemistry laboratory of Energa Kogeneracja in Elblagg. The sample delivered for testing was analyzed in four states: operational, analytical (air-dry), dry and dry ash-free, using the methods listed in Table 1. The expanded uncertainty was determined for $\mathrm{P}=0.95$ and $\mathrm{k}=2$.

The results of the chemical and energy analyses were used to calculate pollution emissions and the coal equivalent of the biomass obtained per ha. The volume of emissions was estimated for the following: sulfur oxides $\left(\mathrm{SO}_{\mathrm{x}}\right.$ converted to $\left.\mathrm{SO}_{2}\right)$, nitrogen oxides $\left(\mathrm{NO}_{\mathrm{x}}\right.$ converted to $\left.\mathrm{NO}_{2}\right)$, carbon monoxide $(\mathrm{CO})$, carbon dioxide $\left(\mathrm{CO}_{2}\right)$, and total suspended particulates (TSP). The computations were performed according to the method proposed by the National Centre for Emissions Management (KOBiZE), using emission factors for individual fuels [Wskaźniki...2015].
The volume of emissions was calculated by the following formula:

$\mathrm{E}=\mathrm{B} \cdot \mathrm{W}$

where:

$\mathrm{E}$ - emission of the substance $[\mathrm{kg}]$

$\mathrm{B}$ - fuel consumption $[\mathrm{Mg}]$

$\mathrm{w}$ - emission factor $\left[\mathrm{g} \cdot \mathrm{Mg}^{-1}\right]$

The emission factors adopted are presented in Table 2.

Parameters of commercially available coal were adopted [Oferta handlowa...], while in the case of multiflora rose biomass it was assumed that it would be dried to the air-dry state prior to combustion. The following parameters were used to calculate emissions:

multiflora rose biomass (on the basis of our own analyses, at a moisture level of $10.2 \%$ ): net calorific value $-15.2 \mathrm{MJ} \cdot \mathrm{kg}^{-1}$, ash content $\mathrm{A}$ $3.1 \%$

hard coal: net calorific value $-24.0 \mathrm{MJ} \cdot \mathrm{kg}^{-1}$, sulfur content $\mathrm{s}-1.0 \%$, ash content $\mathrm{A}-9.0 \%$

The reduction in emissions was defined as the difference between the volume of emissions from combustion of coal and biomass with the same calorific value for 1 ha of the multiflora rose crop.

\section{RESULTS AND DISCUSSION}

Table 1. Laboratory methods

\begin{tabular}{|l|c|c|}
\hline \multicolumn{1}{|c|}{ Parameter } & Standard number & Expanded uncertainty \pm U \\
\hline Analytical moisture & Q/ZK/P/15/05/A:2002, 2.2 & 0.32 \\
\hline Total moisture & Q/ZK/P/15/05/A:2002, 2.1 & 1.51 \\
\hline Ash content & Q/ZK/P/15/06/B:2005 & 0.29 \\
\hline Gross calorific value and calculation of net calorific value & Q/ZK/P/15/12/A:2005 & 225 \\
\hline Total sulfur & Q/ZK/P/15/08/A:2002 & 0.02 \\
\hline Chlorine content & PB 08 w. 01 from May 5, 2009 & 0.02 \\
\hline Carbon content & Q/ZK/P/15/09/A:2002 IS 10 w.02 \\
\hline
\end{tabular}

Table 2. Emission factors (w) for wood and coal

\begin{tabular}{|c|c|c|c|}
\hline \multirow{2}{*}{ Pollutant } & \multirow{2}{*}{ Unit } & Wood & Coal \\
\hline & & $\mathrm{N} \leq 1.0$ & $\mathrm{~N} \leq 0.5$ \\
\hline $\mathrm{SO}_{x} / \mathrm{SO}_{2}$ & \multirow{5}{*}{$\mathrm{g} \cdot \mathrm{Mg}^{-1}$} & 110 & $16,000 \cdot s$ \\
\hline $\mathrm{NO}_{x} / \mathrm{NO}_{2}$ & & 1,000 & 2,200 \\
\hline $\mathrm{CO}$ & & 26,000 & 45,000 \\
\hline $\mathrm{CO}_{2}$ & & $1,200,000$ & $1,850,000$ \\
\hline Total suspended particulates (TSP) & & $1,500 \cdot A$ & $1,000 \cdot A$ \\
\hline
\end{tabular}

Note: $\mathrm{N}$ - nominal boiler output, A - ash content ( $\%), \mathrm{s}$ - total sulfur content (\%)

Source: Wskaźniki emisji zanieczyszczeń ze spalania paliw. Kotły o nominalnej mocy cieplnej do 5 MW. KOBiZE IOŚ-PIB, Warsaw 2015. 
The fresh mass yield of multiflora rose was $20.4 \mathrm{Mg} \cdot \mathrm{ha}^{-1}$ at a moisture level of $50.2 \%$, which gives $10.2 \mathrm{Mg} \cdot$ ha $^{-1}$ of dry mass (DM). This yield was comparable to that obtained by other authors [Antonkiewicz et al. 2016, Chołuj et al. 2010, Kościk 2007, Podlaski et al. 2009], and in some cases even higher [Tworkowski et al. 2010]. Biomass yield in the air-dry state $(10.2 \%$ moisture $)$ was $12.2 \mathrm{Mg} \cdot \mathrm{ha}^{-1}$, and this value was used to calculate pollution emissions.

Ash content in the multiflora rose biomass, at a level of 3.5\% DM (Table 3), was somewhat lower than that described in the literature [Kościk 2007, Kowalczyk-Juśko 2010a, 2011, Winnicka et al. 2010], which may have been due to contamination of the shoots during harvest. The thin, spreading, tangled branches of multiflora rose plants
(Fig. 1) impede the collection and transport of the biomass, which easily becomes contaminated with soil, as discussed in previous studies [KowalczykJuśko 2010b]. According to Kieć et al. [2011], the thin shoots of multiflora rose are an advantage, as they can be harvested by machines of less strength than in the case of plants such as willow.

The energy parameters of multiflora rose stems (GCV - 18.5 and NCV - 17.2 $\mathrm{MJ}^{\mathrm{kg}} \mathrm{kg}^{-1}$ ) in the dry state were comparable to those obtained by other authors and typical of various types of biomass [Kościk 2007, Kowalczyk-Juśko 2010a, 2010b, Winnicka et al. 2010]. The low calorific value determined in the operational state (9.2 and $7.3 \mathrm{MJ} \cdot \mathrm{kg}^{-1}$, respectively) was due to the high moisture content of the biomass, which is typical of woody and semi-lignified plant material. The

Table 3. Chemical composition and energy parameters of multiflora rose biomass

\begin{tabular}{|l|c|c|c|c|c|c|}
\hline \multirow{2}{*}{ Parameter } & \multirow{2}{*}{ Symbol } & \multirow{2}{*}{ Unit } & \multicolumn{4}{c|}{ State } \\
\cline { 4 - 6 } & & & operational & analytical & dry & dry and ash-free \\
\hline Moisture & $\mathrm{W}_{\mathrm{c}}$ & $\%$ & 50.2 & 10.2 & - \\
\hline Ash & $\mathrm{A}$ & $\%$ & 1.7 & 3.1 & 3.5 \\
\hline Burnt matter & - & $\%$ & 48.0 & 86.7 & 96.5 & - \\
\hline Gross calorific value GCV & $\mathrm{Q}_{\mathrm{s}}$ & $\mathrm{kJ} \cdot \mathrm{kg}^{-1}$ & 9,221 & 16,642 & 18,532 & 19,195 \\
\hline Net calorific value NCV & $\mathrm{Q}_{\mathrm{i}}$ & $\mathrm{kJ} \cdot \mathrm{kg}^{-1}$ & 7,339 & 15,209 & 17,214 \\
\hline Total sulfur & $\mathrm{S}_{\mathrm{t}}$ & $\%$ & 0.04 & 0.07 & 0.08 & 17,831 \\
\hline Chlorine & $\mathrm{Cl}$ & $\%$ & 0.02 & 0.03 & 0.08 \\
\hline Carbon & $\mathrm{C}$ & $\%$ & 24.4 & 44.1 & 49.1 & 0.04 \\
\hline
\end{tabular}

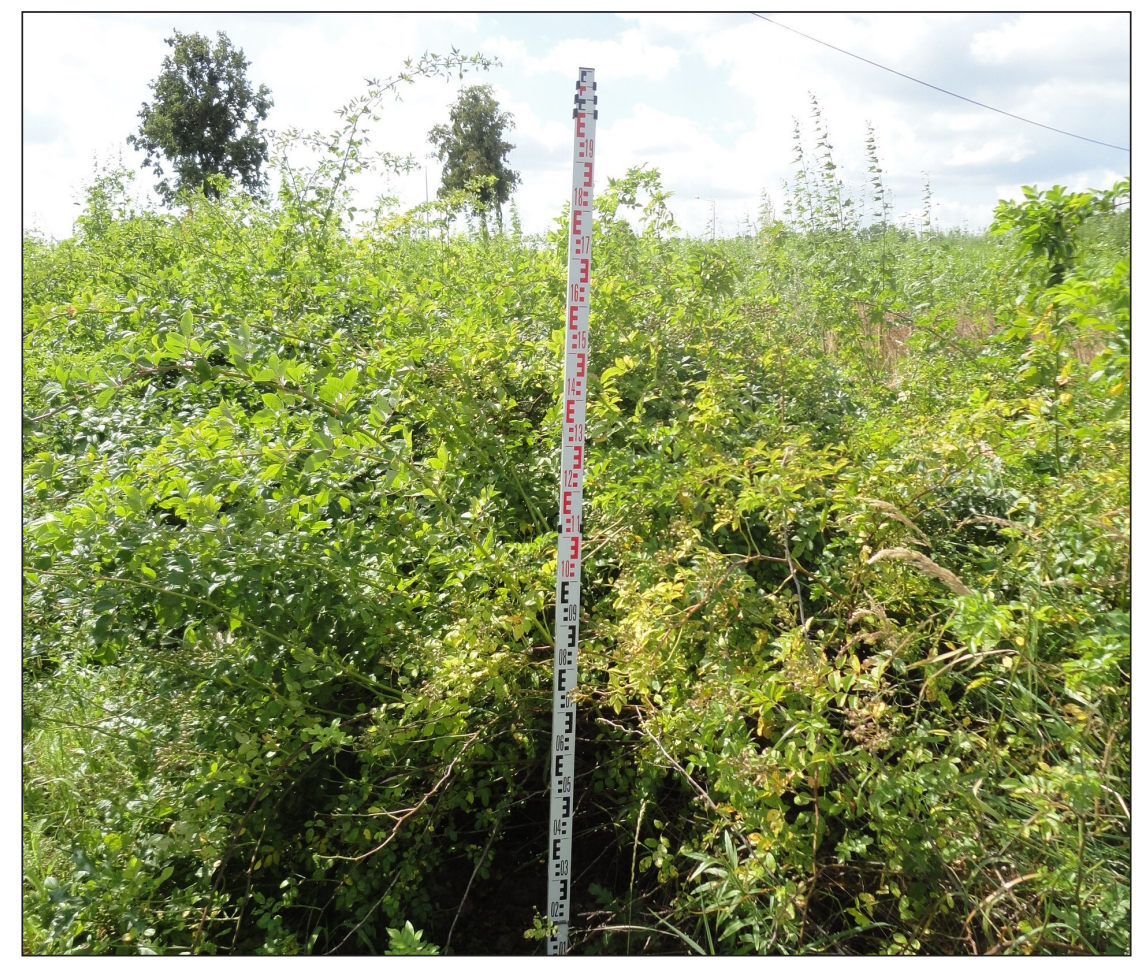

Figure 1. Habit of mulitflora rose shrubs 
calorific value of fuels determined in the dry state is most influenced by their stage of carbonization [Ściążko et al. 2007]. Carbon content in the biomass was $49.1 \%$ DM.

Biomass is used for energy mainly because of its lighter environmental impact as compared to fossil fuels. Nevertheless, biomass also contains harmful components: sulfur and chlorine. During combustion sulfur compounds undergo substantial chemical changes. Iron sulfides undergo exothermic decomposition generating corrosive sulfur dioxide and sulfur trioxide, as well as iron and its compounds. These have a negative impact on the properties of slag and melt with the heating surface of the power boiler. Volatile sulfur compounds, in addition to nitrogen oxides, become extremely toxic atmospheric components [Ratajczak, Stachura 2002]. The total sulfur content in the multiflora rose was $0.08 \%$ DM. In studies by various authors this indicator has ranged from $0.047 \%$ [Kościk 2007] to 0.13\% [Kieć et al. 2011]. An equally wide range has been noted in the case of chlorine content: from $0.014 \%$ [Kościk 2007] to $0.048 \%$ [Winnicka et al. 2010]. In the present study chlorine content was $0.04 \%$ DM.

The calorific value of the multiflora rose obtained per ha was $185.4 \mathrm{GJ}$, which can replace 7.7 $\mathrm{Mg}$ of hard coal. The results of the calculations performed according to the recommended method [Wskaźniki... 2015] indicate that replacement of hard coal with multiflora rose biomass of the same calorific value reduces emissions of most air pollutants (Table 4). Only $\mathrm{CO}_{2}$ emissions calculated for multiflora rose biomass were greater than for hard coal, at $14.64 \mathrm{Mg}$. Despite the substantial amount of $\mathrm{CO}_{2}$ released into the atmosphere by biomass combustion, it is not included in the total emissions from fuel combustion, according to IPCC guidelines [IPCC/OECD 1995]. It should be emphasized that the calculations were performed for the fuels, not for the combustion process in a specific installation. Some of the carbon remaining in the waste modifies gas emissions [Błachowicz, Levina 2003], but at the stage of fuel evaluation such a calculation is not possible.

\section{CONCLUSIONS}

The chemical composition of multiflora rose (Rosa multiflora) biomass and its energy parameters are comparable to other types of plant biomass. A negative characteristic of this biomass is its high moisture level during harvest, which necessitates drying prior to combustion.

The ecological effect of a change in fuel from conventional (hard coal) to multiflora rose biomass is a reduction in emissions of air pollutants: $\mathrm{SO}_{2}, \mathrm{CO}, \mathrm{NO}_{2}$ and particulates. Biomass combustion increases $\mathrm{CO}_{2}$ emissions into the atmosphere in comparison with combustion of coal with the same calorific value. However, carbon dioxide emissions from biomass combustion are considered equal to zero because the $\mathrm{CO}_{2}$ emitted during combustion is absorbed by the growing plants.

\section{REFERENCES}

1. Antonkiewicz J., Kołodziej B., Bielińska E.J. 2016. Phytoextraction of heavy metals from municipal sewage sludge by Rosa multiflora and Sida hermaphrodita. International Journal of Phytoremediation, doi.org/10.1080/15226514.2016.1225283

2. Błachowicz A., Levina E. 2003. Przewodnik po monitorowaniu, raportowaniu i weryfikacji (MRV) emisji gazów cieplarnianych dla przedsiębiorstw. Center for Clean Air Policy, Washington.

3. Burczyk B. 2011. Biomasa. Surowiec do syntez chemicznych i produkcji paliw. Oficyna Wydawnicza Politechniki Wrocławskiej, Wrocław.

4. Chołuj D., Podlaski S., Pietkiewicz S., Wiśniewski G. 2010. Parametry fizjologiczne determinujące plon biomasy roślin energetycznych. [W:] Nowoczesne technologie pozyskiwania i energetycznego wykorzystania biomasy, red. P. Bocian, T. Golec, J. Rakowski. Instytut Energetyki, Warszawa, 69-88.

5. IPCC/OECD 1995. Greenhouse Gas Inventory Reference Manual. IPCC Guidelines for National Greenhouse Gas Inventories. Bracknell, UK, 3, $1-145$.

6. Kieć J., Łabza T., Wieczorek D. 2011. Róża wielokwiatowa (Rosa multiflora) odmiany Jatar na cele energetyczne. Fragm. Agron. 28(3), 35-41.

Table 4. Emission of air pollutants and their reduction after substitution of hard coal with multiflora rose bio$\operatorname{mass}\left[\mathrm{kg} \cdot \mathrm{ha}^{-1}\right]$

\begin{tabular}{|l|c|c|c|c|c|}
\hline \multicolumn{1}{|c|}{ Specification } & $\mathrm{CO}$ & $\mathrm{CO}_{2}$ & $\mathrm{NO}_{2}$ & $\mathrm{SO}_{2}$ & $\mathrm{TSP}$ \\
\hline Emission from coal equivalent & 346.5 & 14245 & 16.9 & 123.2 & 69.3 \\
\hline Emission from biomass combustion & 317.2 & 14640 & 12.2 & 1.3 & 56.7 \\
\hline Reduction of emission (\%) & 8.5 & -2.8 & 27.8 & 98.9 & 18.2 \\
\hline
\end{tabular}


7. Kołodziej B., Matyka M. (red.) 2012. Odnawialne źródła energii. Rolnicze surowce energetyczne. PWRiL, Poznań.

8. Kościk B. 2007. Surowce energetyczne pochodzenia rolniczego. Wyd. PWSZ, Jarosław.

9. Kowalczyk-Juśko A. 2010a. Porównanie składu chemicznego i wartości energetycznej biomasy wybranych gatunków roślin. Pamiętnik Puławski $152,131-140$.

10. Kowalczyk-Juśko A. 2010b. Badania nad energetycznym wykorzystaniem wybranych gatunków roślin wieloletnich. Zeszyty Problemowe Postępów Nauk Rolniczych, 556, 421-427.

11. Kowalczyk-Juśko A. 2011. Properties of ash in the combustion of selected energy crops. Ecological Chemistry and Engineering A. 18, 7, 973-982.

12. Kowalczyk-Juśko A., Kościk B., Kościk K. 2007. Odnawialne źródła energii jako element stabilnego rozwoju gmin wiejskich. [W:] Polska wieś w Unii Europejskiej, red. T. Guz, P. Marzec, Z. Michalski. WZNPiE KUL, Tomaszów Lubelski - Lublin, 61-80.

13. Oferta handlowa. http://pgg.pl/sprzedaz-wegla/oferta-handlowa/rynek-pozostaly; dostęp 10.09.2016

14. Podlaski S., Chołuj D., Wiśniewski G. 2009. Kryteria wyboru roślin energetycznych do uprawy w określonych warunkach przyrodniczych. Wieś Jutra, 8-9 (133/134), 15-17.
15. Ratajczak T., Stachura E. 2002. Formy mineralne siarki w węglu brunatnym ze złoża "Bełchatów". Mat. XXV Symp. Geol. form. węgl. Polski, Wyd. AGH, Kraków, 141-144.

16. Rozporządzenie Ministra Środowiska z dnia 12 września 2008 r. W sprawie sposobu monitorowania wielkości emisji substancji objętych wspólnotowym systemem handlu uprawnieniami do emisji. Dz.U. Nr 183, poz. 1142 z późn. zm.

17. Ściążko M., Zuwała J., Pronobis M. (red.) 2007. Współspalanie biomasy i paliw alternatywnych w energetyce. IChPW, Politechnika Śląska. Zabrze.

18. Tworkowski J., Kuś J., Szczukowski S., Stolarski M. 2010. Produkcyjność roślin uprawianych na cele energetyczne. [w:] Nowoczesne technologie pozyskiwania i energetycznego wykorzystania biomasy, red. P. Bocian, T. Golec, J. Rakowski. Instytut Energetyki, Warszawa, 34-49.

19. Winnicka G., Matuszek K., Wilk B. 2010. Badania właściwości energetycznych, emisyjnych i użytkowych biopaliw uzyskanych ze zbiorów doświadczalnych roślin energetycznych. [W:] Nowoczesne technologie pozyskiwania i energetycznego wykorzystania biomasy, red. P. Bocian, T. Golec, J. Rakowski. Instytut Energetyki, Warszawa, 145-158.

20. Wskaźniki emisji zanieczyszczeń ze spalania paliw. Kotły o nominalnej mocy cieplnej do $5 \mathrm{MW}$. KOBiZE IOŚ-PIB, Warszawa 2015.

Pracę dofinansowano ze środków Wojewódzkiego Funduszu Ochrony Środowiska i Gospodarki Wodnej w Lublinie. 